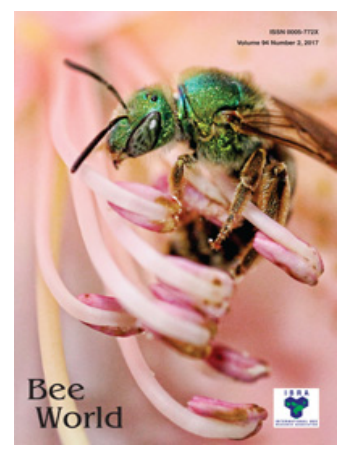

Bee World

ISSN: 0005-772X (Print) 2376-7618 (Online) Journal homepage: http://www.tandfonline.com/loi/tbee20

\title{
Gender Roles and Constraints in Beekeeping: A Case from Kitui County, Kenya
}

\section{Peter Denis Muiruri Mburu, Hippolyte Affognon, Patrick Irungu, John Mburu \& Suresh Raina}

To cite this article: Peter Denis Muiruri Mburu, Hippolyte Affognon, Patrick Irungu, John Mburu \& Suresh Raina (2017) Gender Roles and Constraints in Beekeeping: A Case from Kitui County, Kenya, Bee World, 94:2, 54-59, DOI: 10.1080/0005772X.2016.1275490

To link to this article: http://dx.doi.org/10.1080/0005772X.2016.1275490

\section{曲 Published online: 12 May 2017.}

Submit your article to this journal

Q View related articles $₫$

View Crossmark data $\nearrow$ 


\section{Gender Roles and Constraints in Beekeeping: A Case from Kitui County, Kenya}

\section{Peter Denis Muiruri Mburu ${ }^{\circledR}$, Hippolyte Affognon, Patrick Irungu, John Mburu ${ }^{\oplus}$ and Suresh Raina}

\section{Introduction}

Beekeeping is a form of agriculture that involves management of wild or domesticated bee colonies for production of honey and wax. Generally, in Kenya, women perform most of the agricultural activities (GOK, 2005; Oduol et al., 2013). Even though they play a major role in these activities, they end up receiving a fraction of the income generated. In most of the African countries, beekeeping has often been a male-dominated enterprise (Nel \& Illgner, 2004; Ogaba \& Akongo, 2001; Shackleton, Paumgarten, Kassa, Husselman, \& Zida, 2011). However, with intervention from rural development agencies, a change in this practice could occur.

Beekeeping has been promoted by various governmental and non-governmental organizations in rural Kenya. Their main focus has been to reduce food insecurity, unemployment and improve the people's social well-being (Raina, Kioko, Gordon, \& Nyandiga, 2009). Examples of such organizations include the Kenya Forest Service (KFS) and international organizations such as United Nations Development Program (UNDP) and the International Centre of Insect Physiology and Ecology (ICIPE). Mwingi is part of the arid and semi-arid lands of Kenya where conventional agriculture does not thrive (Gachimbi, de Jager, van Keulen, Thuranira, \& Nandwa, 2002). Therefore, a majority of Mwingi residents relied upon the environment to meet their needs through burning of the existing indigenous vegetation. The predominant tree species felled for this activity was the Acacia tortilis, which produces numerous pods that function as a nutritious food source for goats and sheep, while the tree's flowers are rich in nectar, allowing for honey production. Owing to this beneficial trait of the tree species, beekeeping was championed to curtail felling of trees.

In 2007 ICIPE implemented the Commercial Insect Programme (CIP) in Mwingi Central, North and West Sub-Counties. The programme activities included distribution of modern Langstroth hives, the introduction of stingless bees and their bee hives, farmer training and the development of a honey processing organization that allowed for extracting, bottling, labelling and branding of beehive products (Kioko, 2010). The latter activity involved the formation of farmer coops for bulk production and marketing of honey. The introduction of stingless bees and the provision of Langstroth style bee hives was intended to encourage women to participate in beekeeping. Bee care and honey harvest chores could be carried out during the day alongside other typical household chores. In addition, placing the hives in close proximity to the ground enabled the women to overcome previous cultural constraints such as the need to climb trees in order to harvest honey (Raina et al., 2009). Following the introduction of the CIP, beekeeping, previously was a male dominated enterprise, has now become an important economic activity in Kitui County for both men and women. How beekeeping and the commercialization of its products has influenced gender roles in honey production and marketing remains unknown. We thus investigated the roles of men and women in beekeeping.

\section{An Overview of Female Involvement and Gender Roles in Beekeeping}

Previous studies have shown that beekeeping has often been considered a male-dominated enterprise in Uganda, Kenya and Zambia (Mujuni, Natukunda, \& Kugonza, 2012; Shackleton et al., 2011;
Vlek, Denich, Martius, van de Giesen, \& Gichora, 2003). Further research indicates that women are increasingly taking up beekeeping as an income generating activity in Nyando and Mwingi, Kenya (Macoloo, Recha, Radeny, \& Kinyangi, 2013, Raina et al., 2009). However, they often encounter social and cultural constraints that hinder them from performing apiary management practices (Qaiser, Ali, Taj, \& Akmal, 2013). Some of the constraints faced by women in Uganda were lack of time, bee-sting phobia, inability to hoist and harvest from the traditional beehive (Chemurot, 2011; Ogaba \& Akongo, 2001; Qaiser et al., 2013). Despite this, beekeeping is an important activity for most farmers and has evolved into a vital income source for both men and women (Nel \& Illgner, 2004).

In lower Nyando, the Kenyan ministry of livestock found it easier to roll out modern beekeeping technology to farmers within groups. They observed that 70\% of the active members within beekeeping groups were women (Macoloo et al., 2013). Qaiser et al. (2013) found that women beekeeping groups encountered numerous challenges, because members were unable to perform some of the apiary management practices due to cultural restraints, such as honey harvesting which required one to climb a tree, while groups in Uganda composed of both genders did not face the same problems. Another study noted that participation of women in beekeeping was more likely within mixed gender groups, where tasks like hoisting beehives and harvesting honey could be completed by men, while the women focused on tasks like honey processing. Female participation fell when all tasks had to be carried out by individuals (Nel \& Illgner, 2004). At the Kenya Coast, PactKenya (2010) found that formation 
of beekeeping groups led to more women getting involved. In Kitui County, beekeepers in Mwingi Central, Mwingi West and Mwingi North Sub-counties were organised into groups that had a gender ratio of 1:1 at inception and roll out of the CIP in the year 2007 (Kioko, 2010; Raina et al., 2009).

Ogaba and Akongo (2001) established that some of the factors that deterred women from participating in beekeeping in Uganda included lack of time at night when honey is usually harvested, and the nature of the bees kept. The African bee, Apis mellifera is common and known to be aggressive. Therefore, many apiary tasks such as harvesting honey from beehives inhabited by the African bee are typically done at night, when temperatures drop and the bees are less active and thus less aggressive. But at night women are often expected to be carrying out household chores (Qaiser et al., 2013). In Kenya, Raina et al. (2009) found that training beekeepers in Kitui County in techniques of modern apiculture addressed some of the challenges experienced by women. The training encouraged the use of bee suits to protect the beekeeper from bee stings when harvesting honey during the day, a time at which bees are more aggressive. In addition, due to the introduction of the Langstroth hives that were stationed near ground level instead of high up in trees, honey harvesting could be done easily without having to climb trees, as tree climbing is culturally unacceptable for women.

Both men and women have for centuries been involved in beekeeping in many societies. For example, in Southern Africa, traditional beekeeping dates back to the sixteenth century where use of $\log$ hives and smokers to smoke bees during honey harvesting was largely carried out by men in Angola (Nel \& Illgner, 2004). In Zambia, women were more involved at the honey processing stage, where they converted harvested honey into a local beer called "mbote" while men harvested honey, kept records and took minutes during group meetings (Shackleton et al., 2011). At the Kenyan coast, the role of women in beekeeping was cleaning the apiary, watering bees and transporting the hives to the apiary, while men offered security, repaired the hives, harvested and marketed honey (PactKenya, 2010). In Pakistan, women started assisting in beekeeping as an income generating activity after encouragement and training through development agencies (Qaiser et al., 2013). Some of the apiary activities carried out by women in Pakistan include feeding bees with supplements, extraction of honey from combs and packaging. Men on the other hand, replaced bee colonies, breed queens, harvested and marketed processed honey. As observed from literature, gender roles in beekeeping vary from one country to another. With the increased use of modern beekeeping technology and the involvement of development agencies, apiary roles performed by women increasingly resemble tasks traditionally done by men (Presser \& Sen, 2000).

Studies by Vlek et al. (2003) and Macoloo et al. (2013) in Baringo County and in Lower Nyando of Kenya, for example, noted that more women are participating in beekeeping as an income activity with the aim of improving their livelihoods. Additionally, Nel and Illgner (2004) argued that beekeeping can enhance the position and income of a woman in a society. The current study stratifies apiary cultural activities by gender to clearly highlight activities carried out by each of them. Further, it assesses the influence of the CIP on apiary gender roles among beekeepers in Kitui County.

\section{Methodology}

\section{Study Area}

This study was conducted in Mwingi Central, Mwingi North and Mwingi West sub-counties located in Kitui County, Kenya. The three sub-counties are part of the Arid and Semi-Arid Lands (ASAL) of Kenya which have a heterogeneous type of vegetation. The county is covered by various combinations of bush-land, grasslands and shrubs. It is hot through-out the year with temperature ranging between 24 and $30^{\circ} \mathrm{C}$ with an average annual rainfall of about $300 \mathrm{~mm}$ (Opiyo, Mureithi, \& Ngugi, 2011). These areas have a low potential for conventional agriculture and most of the population derives its livelihood from the forests. Beekeeping is, therefore, a vital source of income to the residents of this region.

In the year 2007-2013, ICIPE implemented the CIP in Kitui County, promoting apiculture as a source of revenue (Mburu, 2015). The aim of the project was to conserve the environment through creation of income generating activities such as beekeeping. Farmers participating in the CIP were organised into groups for collective marketing of honey. They were trained in practical techniques of managing honey bees. Development of a value chain was meant to increase farmers' bargaining power in selling their finished products. Their bee products were certified as organic by the Kenya Organic Agricultural Network (KOAN), thereby enabling farmers to access international markets.

\section{Sampling and Data Collection}

Primary data were collected using a pretested, semi-structured questionnaire. The questionnaire asked who owned the beehives, who managed the apiary, watered the bees, transported hives to the apiary, hired apiary labour, paid apiary labour, repaired beehives, harvested and sold the honey, who decided to set up the beekeeping enterprise, who decided the type of beehives to be used and who sourced the smoker and bee suits, among others. The survey respondents included both CIP beneficiaries and non-beneficiaries. The non-beneficiaries were used for comparison of gender roles before the project. The CIP beneficiaries registered with farmer groups were 1,815 . Of these, 251 farmers were selected using a random number generator in Microsoft Excel, as the Cochran formula (Cochran, 1963) suggested a minimum of 245.8 to have significant level of precision. A similar number of non-beneficiaries were identified for interview as well.

Village elders helped locate the residences of the interviewees. Data collection clerks recruited and trained, were locals who had attained college education. Recruitment of locals was necessary for overcoming language barrier especially in situations where the interviewee could not comprehend Kiswahili or English languages. The survey was conducted over a period of 35 days between 13 May 2013 and 21 June 2013.

\section{Data Analysis}

Data entry was done on Excel while cleaning, coding, computation of descriptive statistics and data analysis were done on Stata software version 13 (Stata Corp, College Station, TX). Differences in gender roles were determined using descriptive statistics such as frequencies and means. Comparison of continuous variables among the two groups was achieved through the two group mean comparison test at $5 \%$ level of significance while categorical variables were compared using the two group test of proportion. Socio-demographic characteristics among CIP and non-CIP were compared using a $t$-test.

\section{Assessing Differences in Gender Roles}

The use of an activity calendar has been applied previously in identification of 
what men and women do on a day-to-day basis (Meyers \& Jones, 2012). In this study however, because agricultural practices are seasonal in nature and production occurs in cycles, an activity calendar could not conclusively capture division of labour in beekeeping. Therefore, apiary maintenance practices and other farm enterprise cultural practices that are carried out within a season were identified and stratified by gender. In addition, ownership of household, livestock and farm assets was stratified by gender.

\section{Results and Discussion}

\section{Respondents' Socio-economic Characteristics}

The mean age of household heads was significantly higher among CIP than non-CIP beneficiaries $(p<0.001)$

(Table 1). The CIP households heads had significantly more experience in beekeeping compared to their counterparts $(p<0.001)$. It is argued that farmers with more experience and age can predict future outcomes of the enterprise based on past encounters (Affognon et al., 2015). Consequently, CIP farmers were found to be older and exhibit more years of experience on average compared to those in the control group. In addition, Chirwa (2005) found that age was positively related to adoption of new technologies in Malawi.

Household heads of non-CIP trended toward more education than their CIP counterparts $(p=0.0885)$. This was contrary to the expectation that farmers, who
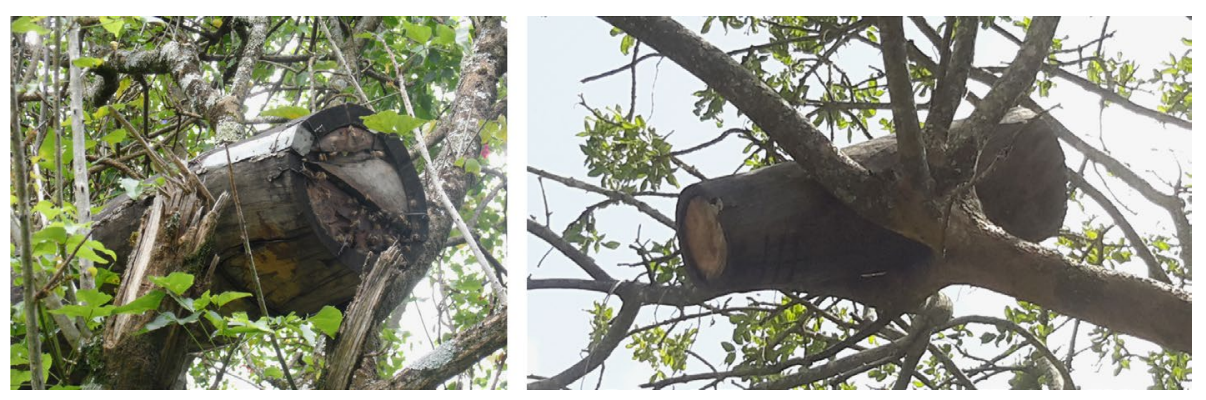

$\Delta$ Figure 1. Photo of a traditional hive hoisted on a tree.

are more educated are likely to participate in a teaching group, because they understand the benefits (Doss \& Morris, 2001). CIP farmers had fewer years of formal education with a mean of 5.74 years of schooling compared to 6.42 years of schooling among non-CIP.

CIP households had a significantly higher number of economic dependants compared to non-CIP ones $(p=0.0447)$. A high dependency ratio implies that such a household would require more income to cater for the needs of dependants and women would have to allocate more time to taking care of the young ones (Hess, 1998). The CIP processing plant offered a market for surplus honey and purchased comb honey from farmers at a constant price of Ksh 200 (1.96 USD $\left.{ }^{1}\right)$ per kilogram unlike other market actors who offered a lower price. This finding tallies with that of Vlek et al. (2003) who found that farmers who sold their honey through a group received more money than those who sold it as individuals. This greater financial return would boost their income to help provide for their household.
CIP households had significantly more income on average compared to those in non-CIP $(p<0.001)$. The average annual beekeeping income among CIP households was Ksh 14,882 (145.90 USD) compared to Ksh 6,665 (65.34 USD) among non-CIP farmers. This was more than double the revenue for non-CIP farmers and can be attributed to the development of a value chain through which the CIP beneficiaries sold their honey. Raina et al. (2009) argued that development of a value chain was vital in boosting the farmer's income security by deriving optimal returns from environmental conservation. In addition, this finding tallies with that of Affognon et al. (2015) who found that farmers in CIP had a relatively higher income from beekeeping compared to non-CIP farmers.

Significantly more CIP than non-CIP households had access to credit $\left(\chi^{2}=7.8\right.$; $p=0.0052$ ) Table 1 . Access to credit among beekeepers is important for the improvement of small holder agriculture (Otieno, Nyikal, \& Mugivane, 2010). Income levels

$\nabla$ Table 1. Summary of socio-economic characteristics of survey respondents in Kitui County, Kenya.

\begin{tabular}{|c|c|c|c|}
\hline Characteristic & Mean for CIP beneficiaries & Mean for non-CIP beneficiaries & $t$-value \\
\hline \multicolumn{4}{|l|}{ Household characteristics } \\
\hline Dependency ratio (\%) & 80.51 & 66.16 & -2.01 **⿻丷木大 \\
\hline Household size (persons) & 5.57 & 5.86 & 1.49 \\
\hline \multicolumn{4}{|l|}{ Farmer characteristics } \\
\hline Age of household head (years) & 55.46 & 48.55 & $-5.93^{* * * *}$ \\
\hline Education of household head (years) & 5.74 & 6.42 & I.71* \\
\hline Education of spouse (years) & 4.28 & 5.15 & $2.24 * *$ \\
\hline Credit access by the household head (credit $=1$, no credit $=0$ ) & 0.10 & 0.04 & -2.81 ***** \\
\hline Accessed credit in the last 5 years (man, yes $=1$, no $=0$ ) & 0.08 & 0.02 & $-2.64 * * * *$ \\
\hline Accessed credit in the last 5yrs (woman, yes $=1$, no $=0$ ) & 0.05 & 0.02 & $-1.70 *$ \\
\hline Gender or sex of household head ( $\operatorname{Man}=1$, female $=0$ ) & 0.90 & 0.91 & 5.48 \\
\hline Experience in beekeeping (years) & 20.84 & 15.55 & -5.52 ***** \\
\hline \multicolumn{4}{|l|}{ Farm characteristics } \\
\hline Beekeeping income (annual in Kenya shilling) & | 4,882.37 & $6,665.47$ & -3.99 ***** \\
\hline Income from other sources (annual in Kenya shilling) & $78,437.37$ & $65,322.71$ & $-2.19 * *$ \\
\hline Quantity of honey harvested (kilograms) & 81.60 & 46.10 & -3.93 ***** \\
\hline
\end{tabular}

Notes: The asterisks denote significance level; ${ }^{*}$ at $10 \%,{ }^{* *}$ at $5 \%$ and ${ }^{* * *}$ at $1 \%$.

Page $56 \cdot$ VOL $94 \cdot$ June $2017 \cdot$ Bee World 


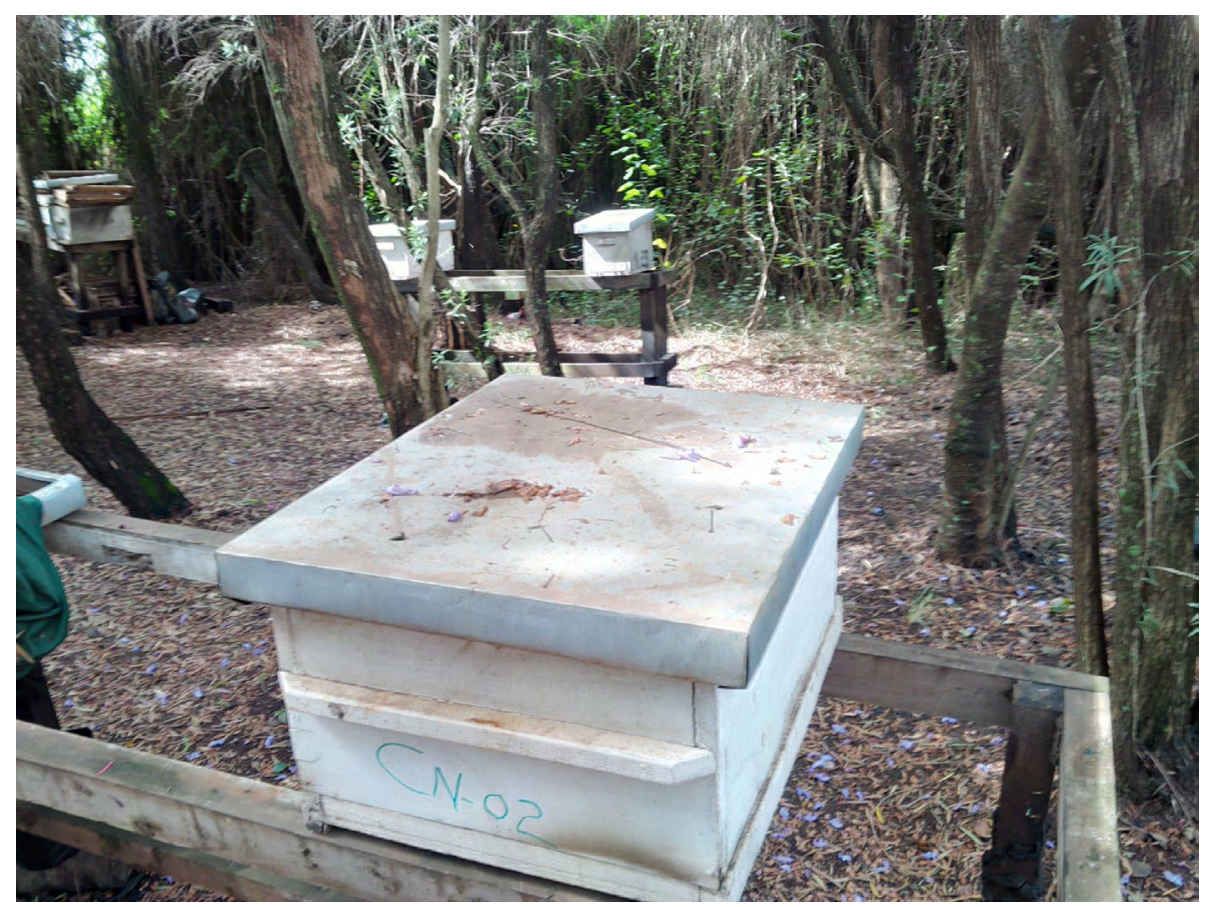

Figure 2. Photo of a Langstroth hive placed near the ground.

could have been a determining factor in credit worthiness of CIP farmers, hence leading to greater eligibility for credit.

The main beehive types used in the study area were traditional hives (Figure 1(a) and (b)), Langstroth hives (Figure 2) and beehives designed for stingless bees. The most commonly used beehive was the traditional hive. On average, CIP farmers owned 30 traditional hives compared to 20 among non-CIP farmers. Langstroth hives owned by CIP beneficiaries were 4.55 hives compared to 0.02 hives among non-CIP on average. Stingless beehives were few among both groups, with CIP farmers keeping an average of 0.31 , while none were kept by non-CIP beneficiaries. Overall, the CIP households had significantly more Langstroth beehives than non-CIP farmers $(p<0.001)$. This can be attributed to the fact that CIP farmers had already formed groups through which they had access to Langstroth hives. In addition, CIP farmers harvested significantly more honey $(81.6 \mathrm{~kg})$ compared to their non-CIP counterparts $(46.1 \mathrm{~kg})(p<0.001)$. This can be attributed to better bee husbandry practices and/or access to improved equipment through the CIP training.

\section{Gender Roles in Beekeeping at the Farm} Level

At the farm level, apicultural practices included cleaning of the apiary, transporting, construction and repair of beehives, watering of bees, as well as managing the apiary. Overall, $68.1 \%$ of CIP men compared to $82 \%$ of non-CIP men undertook apiary activities (Table 2). This finding tallies with that of Ogaba and Akongo (2001), Nel and Illgner (2004), PactKenya (2010) and Shackleton et al. (2011). They found that beekeeping is predominantly a male activity in most African countries. However, it seems that the introduction of the CIP somewhat reduced male dominance in apiary activities in the study area, allowing more women to participate in apiary tasks compared to their non-CIP counterparts. This can be attributed to gender equality and encouragement of women in beekeeping by CIP.

V Table 2. Comparison of apiary activities undertaken by men, women and jointly in Kitui County, Kenya.

\begin{tabular}{|c|c|c|c|c|c|c|c|c|c|}
\hline \multirow[t]{2}{*}{ Apiary activity } & \multicolumn{3}{|c|}{$\begin{array}{l}\text { \% Responses among CIP farmers } \\
\qquad(n=25 I)\end{array}$} & \multicolumn{3}{|c|}{$\begin{array}{l}\text { \% Responses among non-CIP farmers } \\
\qquad(n=247)\end{array}$} & \multicolumn{3}{|c|}{ Comparison of proportions- $Z$ values } \\
\hline & Men & Women & Both & Men & Women & Both & Men & Women & Both \\
\hline Clean apiary & 69.8 & 9.7 & 20.6 & 86.3 & 2.2 & 11.5 & $-4.44 * * *$ & $3.53 * * * *$ & $2.76 * * * *$ \\
\hline Transporting of hives & 69.1 & 4.0 & 26.9 & 78.8 & 5.3 & 15.9 & $-2.46 * * * *$ & -0.69 ***** & $2.99 * * * *$ \\
\hline $\begin{array}{l}\text { Watering of the } \\
\text { apiary }\end{array}$ & 44.8 & 16.9 & 38.3 & 71.7 & 6.2 & 22.1 & $-6.08 * * * *$ & $3.73^{*} * * *$ & $3.93 * * * *$ \\
\hline $\begin{array}{l}\text { Constructing of new } \\
\text { hives }\end{array}$ & 85.1 & 2.8 & 12.1 & 89.4 & 2.2 & 8.4 & -1.44 & 0.43 & 1.36 \\
\hline Repairing of hives & 87.2 & 3.6 & 12.1 & 88.9 & 2.2 & 8.9 & -0.58 & 0.93 & 1.16 \\
\hline $\begin{array}{l}\text { Management of } \\
\text { apiary }\end{array}$ & 52.4 & 6.5 & 42.0 & 77.0 & 2.7 & 20.4 & -5.74 ***** & 2.02 *** & 5.20 ****** \\
\hline Average & 68.1 & 6.1 & 25.3 & 82.0 & 3.5 & 14.5 & $-3.58 * * * *$ & 1.36 & $3.02 * *$ \\
\hline
\end{tabular}

Notes: The asterisks denote significance level; ${ }^{*}$ at $10 \%, * *$ at $5 \%$ and ${ }^{* * *}$ at $1 \%$.

$\nabla$ Table 3. Comparison of apiary activities not done by women among CIP and non-CIP beneficiaries in Kitui County, Kenya.

\begin{tabular}{lccc}
\hline Apiary activities not done by women & $\begin{array}{c}\text { \% Responses among CIP farmers } \\
(n=25 I)\end{array}$ & $\begin{array}{c}\text { \% Responses among NCIP farmers } \\
(n=247)\end{array}$ & $\begin{array}{c}\text { Comparison of proportions- } Z \text { values } \\
\text { Hanging of hives }\end{array}$ \\
Hive construction & 49.6 & 70.0 & $-4.64 * * * *$ \\
Honey harvesting & 30.8 & 27.2 & 0.89 \\
Repairing hives & 19.2 & 2.5 & $5.97 * * *$ \\
\hline
\end{tabular}

Notes: The asterisks denote significance level; ${ }^{*}$ at $10 \%, * *$ at $5 \%$ and ${ }^{* * *}$ at $1 \%$. 
$\nabla$ Table 4. Reasons for women refraining from undertaking apiary activities in Kitui County, Kenya

\begin{tabular}{|c|c|c|c|}
\hline $\begin{array}{l}\text { Reasons for not carrying out the } \\
\text { activities }\end{array}$ & $\begin{array}{l}\text { \% Responses among CIP farmers } \\
\qquad(n=25 \mathrm{I})\end{array}$ & $\begin{array}{l}\text { \% Responses among NCIP farmers } \\
\qquad(n=247)\end{array}$ & Comparison of proportions- $Z$ values \\
\hline They lacked the skills required & 47.5 & 35.8 & $2.65 * * * *$ \\
\hline $\begin{array}{l}\text { Believed that culture prohibited tree } \\
\text { climbing }\end{array}$ & 31.3 & 23.0 & $2.08 * *$ \\
\hline Feared falling from trees & 19.6 & 41.2 & $-5.24 * * * *$ \\
\hline Other reasons e.g., fear of bee sting & 1.7 & 0.01 & $1.88^{*}$ \\
\hline
\end{tabular}

Notes: The asterisks denote significance level; ${ }^{*}$ at $10 \%,{ }^{* *}$ at $5 \%$ and ${ }^{* * *}$ at $1 \%$.

$\nabla$ Table 5. Key decision-maker on beekeeping activities at the farm level in Kitui County, Kenya.

\begin{tabular}{|c|c|c|c|c|c|c|c|c|c|}
\hline \multirow[t]{2}{*}{ Key decisions } & \multicolumn{3}{|c|}{ \% Responses among CIP farmers $(n=25 \mathrm{I})$} & \multicolumn{3}{|c|}{$\%$ Responses among NCIP farmers $(n=247)$} & \multicolumn{3}{|c|}{ Comparison of proportions- $Z$ values } \\
\hline & Men & Women & Both spouses & Men & Women & Both spouses & Men & Women & Both spouses \\
\hline $\begin{array}{l}\text { Who } \\
\text { established } \\
\text { beekeeping }\end{array}$ & 50.2 & 8.6 & 39.6 & 55.7 & 6.6 & 36.9 & -1.23 & 0.84 & 0.62 \\
\hline $\begin{array}{l}\text { Who negotiat- } \\
\text { ed honey sale } \\
\text { price }\end{array}$ & 37.6 & 6.9 & 53.9 & 32.1 & 5.4 & 61.7 & 1.29 & 0.70 & $-1.76 *$ \\
\hline $\begin{array}{l}\text { Who keeps } \\
\text { money from } \\
\text { honey sales }\end{array}$ & 9.8 & 26.5 & 63.7 & 11.1 & 73.4 & 15.6 & -0.47 & $-10.47^{* * * *}$ & $10.96 * * *$ \\
\hline $\begin{array}{l}\text { When and } \\
\text { where to sell } \\
\text { honey }\end{array}$ & 41.0 & 8.2 & 50.0 & 31.6 & 4.5 & 63.1 & $2.18 * * *$ & 1.69* & $-2.95 * * * *$ \\
\hline Overall & 34.6 & 12.6 & 51.8 & 32.6 & 22.4 & 44.3 & 0.47 & $-2.88 * * *$ & $1.67 *$ \\
\hline
\end{tabular}

Notes: The asterisks denote significance level; * at $10 \%,{ }^{* *}$ at $5 \%$ and ${ }^{* * *}$ at $1 \%$.

There are activities that women did not carry out, such as hanging of beehives, beehive construction and repair as well as harvesting of honey (Table 3). Reasons given for refraining from the activities were:

- lack of skills;

- bee sting phobia;

- cultural constraints that prohibited women from climbing trees;

- fear of falling from a tree.

These findings (Table 4) tally with those of Ogaba and Akongo (2001) and Shackleton et al. (2011). However, significantly more women among non-CIP beneficiaries (97.6\%) participated in honey harvesting compared to their CIP counterparts (80.8\%). This finding contradicts ICIPE's expectation, because issuance of bee suits and smokers was meant to address beesting phobia and encourage participation in honey harvesting.

\section{Household Decision-making on Honey Production Activities}

In order to determine the role of women in beekeeping, those who made decisions regarding honey production were sought (Table 5). The main decisions include: who established beekeeping for the household, negotiated honey sale price, and who kept honey sale proceeds. Female involvement in the establishment of beekeeping as an income-generating enterprise showed no significant difference among CIP and non-CIP beneficiaries $(z=0.84 ; p=0.392)$. However, there was a trend toward more women negotiating honey sales in non-CIP compared to their counterparts in CIP $(z=-1.76$; $p=0.0762)$. This difference could be attributed to the fact that CIP farmers sold $65.6 \%$ of the honey to the Community Based Organization (CBO) at a fixed price of Ksh 200 (1.96 USD) per kilo of comb honey. The non-CIP farmers had to negotiate the price with brokers who purchased $76.1 \%$ of their honey.

With regard to who kept the revenue from honey sales, significantly more women than men kept honey revenue amongst both CIP and non-CIP beneficiaries $(z=10.47 ; p<0.001)$. However, more women among non-CIP (73.4\%) than CIP (26.5\%) beneficiaries kept the sale proceeds from honey, which can be attributed to the extensive involvement in negotiation of honey sales compared to those in non-CIP. In addition, among the CIP farmers, joint appropriation of honey sales proceeds was most prevalent (63.7\%), perhaps because of greater consultations

V Table 6. Decision-maker regarding acquisition of key beekeeping inputs among survey households in Kitui County, Kenya.

\begin{tabular}{|c|c|c|c|c|c|c|c|c|c|}
\hline \multirow[t]{2}{*}{ Input } & \multicolumn{3}{|c|}{$\%$ Responses among CIP farmers $(n=25 \mathrm{I})$} & \multicolumn{3}{|c|}{$\begin{array}{l}\text { \% Responses among non-CIP farmers } \\
\qquad(n=247)\end{array}$} & \multicolumn{3}{|c|}{ Comparison of proportions- $Z$ values } \\
\hline & Men & Women & Both spouse & Men & Women & Both spouse & Men & Women & Both spouse \\
\hline Smoker & 90.3 & 5.1 & 3.4 & 87.6 & 5.0 & 6.9 & 0.96 & 0.05 & $-1.77 *$ \\
\hline Traditional hives & 55.6 & 25.6 & 18.4 & 44.7 & 22.0 & 33.3 & $2.43^{* * *}$ & 0.94 & 3.80****** \\
\hline Langstroth hives & 28.0 & 44.0 & 28.0 & 0 & 0 & 0 & $8.97 * * *$ & $11.82 * * *$ & $8.97 * * * *$ \\
\hline
\end{tabular}

Notes: The asterisks denote significance level; ${ }^{*}$ at $10 \%,{ }^{* *}$ at $5 \%$ and ${ }^{* * *}$ at $1 \%$. 
between spouses during negotiation of the honey sale price (53.9\%).

\section{Household Decision-making on Sources of Inputs}

The main inputs required for one to become a beekeeper included a beehive, a smoker and bee suit. The decision to acquire a smoker was dominated by men among both CIP (90.3\% men vs. $5.1 \%$ women) and non-CIP (87.6\% men vs. $5 \%$ women) beneficiaries (Table 6). Similarly, the decision to acquire traditional hives was also dominated by men in both groups. However, women led in the decision to acquire modern hives among the CIP beneficiaries as evidenced by the fact that $28 \%$ of men vs. $44 \%$ women made that decision. This finding tallies with that of Nel and Illgner (2004) that men preferred the use of traditional hives and smokers for honey harvesting. Since men often had prior beekeeping knowledge using traditional equipment, their preference for traditional hives may simply speak to their familiarity. Modern Langstroth hives required them to learn new management techniques. The preference for modern hives by women could have been due to the fact that these alleviated some of the cultural constraints, since Langstroth hives can be maintained near the ground as opposed to high up a tree as is done with traditional hives. In addition, the movability of frames in Langstroth equipment allows for easier honey harvests, and may reduce bee hostility.

\section{Conclusion}

Findings from this study indicate that more women are participating in apiary management, such as watering, cleaning and management of the hives. In addition, they are also involved in making decisions on the acquisition of Langstroth hives, harvesting gear, honey sales, and use of honey proceeds. Therefore, apicultural training and introduction of modern beekeeping technology among CIP beneficiaries has a positive impact on addressing cultural constraints that hindered women from participating in this male dominated enterprise. Further, more women are taking up beekeeping as an income generating activity. Thus, development projects such as the CIP have the potential to induce changes in gender roles and break cultural barriers in a society.

\section{Note}

I.The currency exchange rate used is Ksh 102 to I USD.

\section{References}

Affognon, H.D., Kingori, W.S., Omondi, A.I., Diiro, M.G., Muriithi, B.W., Makau, S., \& Raina, S.K. (20I5). Adoption of modern beekeeping and its impact on honey production in the former Mwingi District of Kenya: Assessment using theory-based impact evaluation approach. International Journal of Tropical Insect Science, 35, 96-102.

Chemurot, M. (201 I). Beekeeping In Adjumani District, Uganda. Bee World, 88, 58-6I. DOI: I 0.1 080/000577 2X.2011.11417417.

Chirwa, E.W. (2005). Adoption of fertiliser and hybrid seeds by smallholder maize farmers in Southern Malawi. Development Southern Africa, 22(1), I-12.

Cochran, W. (1963). Sampling techniques. New York, NY: John Wiley and Sons.

Doss, C.R., \& Morris, M.L. (200I). How does gender affect the adoption of agricultural innovations? The case of improved maize technology in Ghana. Agricultural Economics, $25,27-39$.

Gachimbi, L.N., de Jager, A., van Keulen, H., Thuranira, E.G., \& Nandwa, S.M. (2002). Diagnosis of soil nutrient depletion in semi-arid areas of Kenya.

GoK. (2005). ASAL gender policy guidelines. Nairobi: Printer Government Press.

Hess, P.N. (1988). Population growth and socioeconomic progress in less developed countries: Determinants of fertility transition. Santa Barbara, CA: Greenwood Publishing Group.

Kioko, E. (20 I0, April). Agfax: Reporting Science in Africa. Retrieved January 30, 20 I3, from Agfax: http://www.agfax.net Macoloo, C., Recha, J., Radeny, M., \& Kinyangi, J. (20 I3). Empowering a local community to address climate risks and food insecurity in Lower Nyando, Kenya. Case study for Hunger, Nutrition and climate justice, A new dialogue; putting people at the heart of global development. Dublin, Ireland.

Mburu, P.D.M. (20I5). Mapping of the honey value chain and analysis of changes in gender roles and factors influencing women empowerment among beekeepers in Kitui county, Kenya (Doctoral dissertation). University of Nairobi, Nairobi.

Meyers, L., \& Jones, L. (20।2). Gender analysis, assessment and audit: Manual and toolkit. Washington, DC:ACDI/VOCA.

Mujuni, A., Natukunda, K., \& Kugonza, D.R. (20I2). Factors affecting the adoption of beekeeping and associated technologies in Bushenyi District, Western Ugandac. Development, 24,8.

Nel, E., \& Illgner, P. (2004). The contribution of bees to livelihoods in southern Africa. Rights, Resources and Rural Development: Community-based Natural Resource Management in Southern Africa, 127-134.

Oduol, J., Place, F., Mithöfer, D., Olwande, J., Kirimi, L., \& Mathenge, M. (20I3). Improving participation in agricultural commodity markets for smallholder avocado farmers in Kenya: Assessing growth opportunities for women in Kandara and Marani districts.
Ogaba, M.R., \& Akongo,T. (200 I). Gender issues in beekeeping - The Uganda case. Durban: In APIMONDIA Congress.

Opiyo, F.E., Mureithi, S.M., \& Ngugi, R.K. (20I I). The influence of water availability on pastoralist's resource use in Mwingi and Kitui Districts in Kenya. Journal of Human Ecology, 35, $43-52$.

Otieno, P.S., Nyikal, R.A., \& Mugivane, F.l. (20 I 0). Non-credit services of group-based financial institutions: Implications for smallholder women's honey income in arid and semi-arid lands of Kenya. African Journal of Agricultural Research, 5 , 344-347.

PactKenya. (2010). Scoping study and value chain analysis for bee keeping and honey products, draft copy. Retrieved from www.PactKenya.org

Presser, H., \& Sen, G. (2000). Women's empowerment and demographic processes: Moving beyond Cairo. Oxford: Oxford University Press.

Qaiser, T., Ali, M.,Taj, S., \& Akmal, N. (20 I 3). Impact assessment of beekeeping in sustainable rural livelihood. Journal of Social Sciences (COES\&RI-JSS), 2, 196-198.

Raina, S.K., Kioko, E.N., Gordon, I., \& Nyandiga, C. (2009). Improving forest conservation and community livelihoods through income generation from commercial insects in three Kenyan forests.

Shackleton, S., Paumgarten, F., Kassa, H., Husselman, M., \& Zida, M. (20I I). Opportunities for enhancing poor women's socioeconomic empowerment in the value chains of three African non-timber forest products (NTFPs). International Forestry Review, |36-|5|.

Vlek, P.L., Denich, M., Martius, C., van de Giesen, N., \& Gichora, M. (2003). Ecology and development series No. 6.

Peter Denis Muiruri Mburu International Centre of Insect Physiology and Ecology (ICIPE), Dudu Ville Station,

P.O. Box 30772-00100, Nairobi, Kenya; Faculty of Agriculture, University of Nairobi, P.O. Box 29053-00625, Kangemi, Kenya

Email: peterdenoh@gmail.com http://orcid.org/0000-0001-8100-6903

Hippolyte Affognon International Centre of Insect Physiology and Ecology (ICIPE), Dudu Ville Station,

P.O. Box 30772-00100, Nairobi, Kenya; International Crops Research Institute for the Semi-Arid Tropics (ICRISAT), BP 320 Bamako, Mali

Patrick Irungu and John Mburu

Faculty of Agriculture, University of Nairobi, P.O. Box 29053-00625, Kangemi, Kenya

http://orcid.org/0000-0001-6762-9979

Suresh Raina International Centre of Insect Physiology and Ecology (ICIPE), Dudu Ville Station, P.O. Box 30772-00100, Nairobi, Kenya 